Article

\title{
Tourists' Perceptions on Climate Change in Lisbon Region
}

\author{
Filomena Clemente ${ }^{1}\left[\right.$, António Lopes ${ }^{2, *}$ and Vitor Ambrósio ${ }^{3(\mathbb{C}}$ \\ 1 Institute of Geography and Spatial Planning (IGOT), Universidade de Lisboa, Rua Branca Edmée Marques, \\ Cidade Universitária, 1600-276 Lisboa, Portugal; filomenaclemente@gmail.com \\ 2 Institute of Geography and Spatial Planning (IGOT), Centre of Geographical Studies, Universidade de \\ Lisboa, Rua Branca Edmée Marques, Cidade Universitária, 1600-276 Lisboa, Portugal \\ 3 Escola Superior de Hotelaria e Turismo do Estoril (Estoril Higher Institute for Tourism and Hotel Studies), \\ Av. Condes de Barcelona 808, 2769-510 Estoril, Portugal; vitor.ambrosio@eshte.pt \\ * Correspondence: antonio.lopes@campus.ul.pt
}

Received: 9 November 2019; Accepted: 14 March 2020; Published: 18 March 2020

check for updates

\begin{abstract}
The interface between climate change and tourism is multifaceted and complex. This research aims to understand the relationship established between the tourists' concerns regarding the impacts of climate change and the risks that may arise and the willingness to pay (WTP) a supplementary fee, and what its value should be, in the tourist packages for environmental sustainability. The empirical phase of this research is presented in the form of a problem: "Will tourists be willing to pay a supplementary fee on tourist packages for environmental sustainability?". To answer this question, a methodology was implemented in which a questionnaire was given to tourists, and the results were elaborated with several descriptive and multivariate statistics were elaborated. The results show that most tourists are not yet willing to pay a supplementary fee on tourist packages for environmental sustainability, but that this value increases with increasing concern about the risks associated with climate change. This research is intended to contribute to the development of more effective policies, in a bottom-up approach, to manage the risks related to climate change, facilitating successful adaptation.
\end{abstract}

Keywords: tourism and climate change; environmental sustainability rate; willingness to pay; Lisbon

\section{Introduction}

The recognition of the role that climate and the weather conditions currently have on the tourism sector has acquired a new importance in recent years. Climate change has been identified as a very important factor for tourist activities in the future [1,2]. According to the Intergovernmental Panel on Climate Change [3] the average global temperature is expected to increase by between 1.1 and 6.4 degrees Celsius, and the sea level can rise by between 18 and $59 \mathrm{~cm}$ or more, within the same period. These projections, according to the Intergovernmental Panel on Climate Change [3], have led to a new interest in the relationship between the weather and tourism and the impact that the climate changes could have on the coastal areas [3].

Climate change is manifested mainly by a rise in the average surface temperature of the atmosphere. This increase in temperature is not spatially uniform but is more pronounced in the polar regions. The average annual temperature increase in Europe from preindustrial times to 2007 was $1.2{ }^{\circ} \mathrm{C}$, higher than the global average temperature increase of $0.8^{\circ} \mathrm{C}$ for the same period. In Portugal, the increase average annual temperature in the period from 1976 to 2006 was close to $0.5^{\circ} \mathrm{C}$ [4].

Another important consequence of climate change is the tendency to increase the frequency and intensity of extreme weather events such as heat waves, droughts and heavy precipitation events 
over short periods [4]. In Europe, during the 20th century, there was an increase in average annual rainfall in the northern part of the continent by $10 \%$ to $40 \%$, and there was a decrease in average annual rainfall of $20 \%$ to $40 \%$ in southern regions [4]. Portugal has seen a slight decrease in average annual rainfall of 30 to $60 \mathrm{~mm}$ per decade over the period from 1961 to 2006 [5]. The SIAM-II results indicate a concentration of rainfall, including torrential rainfall, between December and February which will increase the risk of flooding, especially in the north of the country. Climate change can also cause more than 30\% reduction in rainfall in the south and aggravate current water supply problems [5]. In addition to these aspects, the rise in mean sea level caused indirectly by climate change should also be considered. This rise results from the expansion of ocean surface waters motivated by the increase in its average temperature, as well as the melting of mountain glaciers and ice of glaciers and ice fields above sea level in the polar regions. During the 20th century, the global average increase in sea level was $17 \mathrm{~cm}$, close to the $15 \mathrm{~cm}$ observed in mainland Portugal [5].

It is possible to respond to climate change risk through two types of action strategies: mitigation and adaptation. Mitigation is aimed at halting the increase in atmospheric concentration of greenhouse gases by reducing emissions and developing potential sinks for those gases. Adaptation is the response process in which efforts are made to minimize negative effects and enhance the positive effects of climate change impacts. Mitigation and adaptation are complementary responses that are closely related.

The relationships that are established between climate change and tourism are intense and complex. on the one hand, tourism may be one of the economic activities most affected by climate change; on the other, the tourism sector is also a significant contributor to greenhouse gas emissions [6].

According to Gössling et al. [7], the influence of climate change on tourism demand patterns will be shaped by the response of tourists to the complexity of mitigation and adaptation policies and their impacts on transport systems, as well as the wide range of impacts of climate change on destinations, society and economic development. Consequently, understanding tourists' perceptions and reactions to the impacts of climate change is essential in order to anticipate potential geographic and seasonal changes in tourist demand as well as the decrease or increase in specific tourism markets. However, despite a wide range of publications on environmental change and climate change, little is known about the complexity of tourists' responses.

Most European citizens (95\%) consider that is important to protect the environment, and $72 \%$ are willing to pay more for green products [8]. However, only 17\% buy green/organic products [8]. This shows that the European consumer is very inactive in pro-environmental consumption influenced by socioeconomic reasons, such as purchasing power, education level and tourists' information, among others.

Tourism is an important and expanding sector, both at the global and European levels [9], and can have positive and negative effects in a region. Tourism is a sector that can contribute to the economic growth of a region and produces social benefits (e.g., small and medium-sized enterprises' development, creation of new jobs, improvement of infrastructure). Culturally, tourism is an element of community enrichment, allowing contact between different cultures. Tourism can also positively contribute to the maintenance of a natural environment by protecting, creating or maintaining national parks or other protected areas. However, it is a sector where there is clearly an uneven distribution of benefits, which might threaten the social, economic and environmental sustainability of tourism in some countries [10]. Tourism is one of the economic sectors where climate change is expected to have a substantial impact locally. Conversely, tourism activities contribute to intensify climate changes with an increase in greenhouse gas emissions [6]. Sustainable tourism is becoming increasingly popular [11], but consumers are still passive [12]. Low demand for pro-environmental tourism packages is a barrier to the development of sustainable tourism. Thus, it is important for tourists to start making greener choices. Depending on the services included in a package tour, it can be more or less sustainable.

In order to understand whether tourists take responsibility in the area of sustainable tourism, some studies have examined the willingness of tourists to pay a fee for environmental protection [13-15]. Currently, many alternatives to ecologically sustainable tourism packages are more expensive 
than the less sustainable ones [15], so tourists need to be willing to pay more to opt for more sustainable behaviour.

Many previous studies have focused on total cost rather than the willingness to pay extra for an environmentally sustainable package [15]. This knowledge is important for stakeholders to be able to offer forms of sustainable tourism, and it is necessary to know the value of the rate that tourists are willing to pay.

The main aim of this study is to investigate the relationship between tourists' concern about the risks of climate change and the willingness to pay a fee (and how much they are willing to pay) for environmental sustainability.

The specific objectives are:

(i) To determine whether tourists are sensitive to the impacts of climate change;

(ii) To assess how tourists are sensitive/worried when thinking about climate change and the risks that may arise from it;

(iii) To understand if tourists are willing to pay a supplementary fee for packages for environmental sustainability and how much they are willing to pay;

(iv) To establish relationship between objectives (ii) and (iii).

This study aims at contributing to the development of more effective policies in the Lisbon region, in a bottom-up approach, to manage risks related to climate change, increase resilience and facilitate successful adaptation.

\section{Relevance of Climate Change Adaptations for Tourism}

Climate change is perhaps the most urgent environmental issue today, although the tourism sector is a laggard in discussing challenges and opportunities due to the impact of climate change. Climate change impact and adaptation measures are relevant for tourism.

Traditionally, seasonal contrast drives more concentrated demand for summer holidays, and climate/weather contrast between the countries of origin and destination of tourists creates large tourist flows worldwide, at the European and national levels [16]. Tourism has traditionally been regarded as a highly climate-sensitive economic sector [17], and some types of tourism, for example, "sun and sea" and winter sports (skiing) are particularly climate dependent. Climate and weather are important factors influencing destination image, tourism resources, long-term tourism demand, travel season, duration and quality of tourism, tourism experience and profitability [18-22]. Tourists' decision-making depends on the weather and climatic conditions at the destination and also on the country of origin. The characteristics of national and international tourists and their motivations for travel are diverse and change over time. Thus, the ability of tourists to adapt to changing weather conditions depends on their information and experience. However, evidence shows that the decision to return to a destination is very little affected by past bad weather experiences [23]. Simultaneously tourists can be found in all climates and places with different natural landscapes, and tour operators have to adapt to provide tourism services in all climatic zones of the planet [23]. Major segments of the global tourism market have specific climate/weather needs, opportunities and constraints, so adaptation measures should address the most vulnerable aspects of tourism, with reference to sustainability, cost-effectiveness and principles of social justice.

\section{Tourist Perception and Information Needed}

\subsection{Tourist Perception}

Understanding tourist perceptions and their reactions to the climate change impacts is essential for anticipating the choice of destination and type of vacation, even in the very short term, because tourists have a greater adaptability and flexibility to replace destination, season and type of vacation. 
According to several researchers [7,21,23], the influence of climate change on patterns of tourism demand will be shaped by the response of tourists to the complexity of mitigation policies and their impacts on transportation systems, the wide range of impacts of climate change on destinations and wider impacts on society and economic development.

It is important to underline that the interpersonal perspective is an important factor that might influence tourist's decision-making. Kang et al. [24] investigated dyadic consensus in the family holiday destination selection process, emphasizing spousal conflict arousal dimensions, the strategies used and the satisfaction with the outcome of the decision and the decision-making process. Data were collected through questionnaire interviews with husbands and wives from households in the USA. Hung [25] also remarked that household natural hazard preparedness often relied on individual-level data to predict household-level preparedness behaviors. In doing so he neglected intrahousehold dynamics' influence on household decision-making. Targeting married, heterosexual couples living in Sarasota County, Florida, the study aimed at understanding who the decision-makers are in a three-stage household decision-making process-problem initiation, information search and decision.

Climate, environment, income, discriminatory wealth, personal safety, household decision-making $[24,25]$ and travel costs are key factors in motivation and choice of destination [26]. All these factors seem likely to be affected by climate change [7], and the implications for tourist behavior and local, national and international demand patterns can be profound. Understanding tourist perceptions and reactions to the climate change impacts is therefore essential to anticipating geographical potential and seasonal changes in tourism demand, changes in specific markets and the global competitiveness of companies and destinations.

Climate change impacts on tourism operations and destinations, according to several authors [7,21,27], are closely related to tourist behavior, and four major types of climate change impacts on tourism demand can be distinguished:

(i) direct impacts of climate change;

(ii) indirect impacts of environmental change;

(iii) mitigation and tourism mobility policy; and

(iv) social changes related to low economic growth, consumer cultures and political and social stability.

Most of the literature focuses on the direct and indirect consequences of climate change, and there appear to be no studies providing direct behavioral evidence of how low economic growth or social and political stability affect tourism. There are also few studies evaluating the consequences of tourism mitigation policy [28].

Consequently, understanding tourists' perceptions and reactions to the climate change impacts is essential for anticipating potential geographic and seasonal changes in tourism demand, as well as for decreasing or increasing specific tourist markets [28]. However, despite a wide range of publications on environmental change and climate change, little is known about the complexity of demand responses.

\subsection{Tourists' Information Needs}

Tourists' destination perception is, among other reasons, influenced by the available information. The climate information services in the tourism sector, including existing and emerging applications and services for tourism stakeholders, show knowledge gaps and the need of research and partnerships. Those are necessary to speed up the application of climate information, to manage risks related to weather/climate variability and to enable successful adaptation to climate change [29].

In recent decades, there have been great advances in climatology, namely, the knowledge that anthropogenic greenhouse gas emissions have implications in the global climate system. Innovation in communication technologies, the internet and, more recently, mobile personal data devices (e.g., smartphones) has also changed the climate information available to tourists and tourist activity. Although interest in the climate/tourism interface has increased significantly in the past decade (demonstrated by the number of scientific publications on tourism and climate), the scientific community 
has yet to assess how the progress in information technologies, and information communication on the climate, has resulted in more efficient decision-making in the tourism sector. [30].

Undoubtedly, it is very important to provide significant opportunities to improve decision-making and reduce climate risks in the sector. Collected evidence indicates that climate change, particularly high GHG emissions scenarios, will be a crucial issue which will affect the medium- and long-term tourism's development and management. [18,20,23,31]. Therefore, it is accepted that the need for climate services will grow over the 21st century, as the magnitude of climate change increases and the ability to rely on past experience decreases. [23]. The World Meteorological Organization (WMO) and the World Tourism Organization (WTO) statements indicate that both organizations recognize that improving the use of climate information it is an important strategy, on the one hand, to enable the sustainable development of tourism, and on the other hand, to contribute to the United Nations Millennium Development Goals.

Improving the use of climate information in the tourism sector is a challenge that will require closer collaboration between climate and tourism research. More than two decades ago, Smith [32] argued that the limited research in the complex interactions between climate and tourism is due to the lack of communication between the meteorologists and the leisure experts. Scott and Becken [21] also stressed that there are substantial opportunities to offer more effective climate services, which should be of immediate and noticeable value for tourists and for tourism.

Fortunately, several important new partnerships have emerged in recent years, providing a solid and necessary future collaboration. In 2005, the collaboration between the WMO and the WTO enabled the creation of an international Climate and Tourism experts' team. This cooperation has provided new projections for tourist destinations and training and cooperation to deliver tourism forecasts, among other benefits.

In fact, the tourism sector is characterized by diversity; subsequently, there are wide-ranging differences between climate sensitivity and the capacity of tour operators to incorporate climate services in a decision-making process. Weather and climate have a broad significance for tourism decision-making and for the travel experience, significantly influencing travel and spending patterns around the world. For tourism and tourists, the climate represents both a vital resource to be exploited and an important risk to be managed. The effects of climate change are expected to have deep impacts on tourist demand and on the ability of tourism companies to manage the climate changes in different tourist destinations. Consequently, it is expected that the demand for accurate and detailed information will substantially increase to lessen the challenges of the climate change in the coming decades [33].

\section{Visitors' Willingness to Pay (WTP)}

Human development and dense populations along coastal zones impact the health of coastal and marine ecosystems, as in Lisbon region, which is detrimental to the economic sustainability of tourism.

in the last few years we have seen an increase in research about ecosystem value and the willingness to pay (WTP) for sustainability. In developing countries with limited resources for environmental management, the questions as to who should pay the cost of conservation and what the amount should be have been the subject of much debate.

Schumann et al. [34] concluded with their research that Barbados visitors were primarily attracted to the country's coastal and marine resources, making the protection of the marine environment very important. The authors investigated the factors driving the willingness of tourists to pay a fee for coastal and marine conservation. They suggest that the fee, if implemented, should be paid into a dedicated conservation fund. Furthermore, consideration should be given to charging only non-Caribbean tourists given that regional visitors displayed discontent in paying such fees.

Ndebele and Forgie [35] studied Pekapeka Swamp located in Hawke's Bay, New Zealand. Their paper employed the contingent valuation method to estimate the total economic value of the restoration and preservation of Pekapeka Swamp. These results implied an important investment, which the authorities and tourists should continue to support. 
Faizan et al. [36] studied the coral reef around Cape Rachado in Malaysia. Coral reef studies from 1976 to 2014 in the area indicated that the live coral coverage has declined from 59.6\% to $11.9 \%$. The researchers studied the willingness to pay (WTP) by local tourists for an improved coral reef management scenario for this area. The contingent valuation survey demonstrated that the local visitors were supportive of a conservation fee.

Brouwe et al. [37] estimated the public WTP for alternative management regimes of a network of offshore marine protected areas in the North Sea. Despite the lack of public awareness and familiarity with the offshore marine areas, a majority of $70 \%$ was willing to pay extra tax for their protection. Dutch households are willing to pay on average a maximum $0.25 \%$ of their annual disposable income.

Yu et al. [38] studied two marine protected areas in Zhejiang Province, China and the willingness to pay (WTP) for marine conservation. The results showed that most respondents were willing to pay for marine conservation but were affected by different factors. The probability of respondents' WTP was closely related to their individual environmental awareness, whereas the payment amount was influenced mainly by personal income.

The results of these different papers can be used in policy-makers' decision-making regarding the economic sustainability of tourism.

\section{Data and Methods}

\subsection{Measurements}

The empirical phase of this research paper was presented as a problem: "Are tourists in the Lisbon region aware of the impacts of climate change, and are they willing to pay a fee for environmental sustainability?"

To answer the research question, a bibliographic review was conducted, which led to the identification of the general and specific objectives that were previously stated.

To achieve the proposed objectives, tourists visiting the Lisbon region answered a questionnaire. The research of the international project "Urban Tourism and Climate Change" was adapted to this study. In the exploration phase, the questionnaire was tested among PhD students in tourism and tourism specialists, namely tourist guides (together, approximately ten people), who were all able to make suggestions for its improvement.

This study area of this research is the Lisbon Region. This region is part of the Lisbon Metropolitan Area where the beaches of the south-facing Estoril Coast stand out, forming a continuous line from the Tagus estuary to Cabo Raso. Along the Sintra coast, from S. Julião to the north and Cape Raso to the south, there are numerous beaches bathed by the Atlantic Ocean: Samarra, Magoito, Azenhas do Mar, Praia das Maças, Praia Grande and Adraga, among others [39].

The choice of this region was due to the fact that it meets the conditions for the application of the methodology to be developed, given its intrinsic characteristics, such as morphology, natural resources, climatic conditions and infrastructure that allow the enjoyment of multiple tourism products, e.g., city breaks, nautical and cruise tourism, golf, sun and sea, and cultural tourism, among others. This diversity of tourism products gives the Lisbon Region the characteristics of a "resort destination", in which the complementarity between the city, the river, the beach and nature prevails [40].

The sample used in the study consisted of 1181 respondents, and the answers were collected between 17 July 2014 and 3 September 2015: 51\% of the questionnaires were collected in summer, 24\% in spring, $18 \%$ in winter and $7 \%$ in autumn.

In order to understand the extent of tourist awareness about climate change and its consequent associated risks, five questions were asked (referenced as " $\mathrm{Qn}$ " in the figures and tables in this text): Q1: "Should tourism products have information about their ecological footprint (amount of $\mathrm{CO}_{2}$ emissions)?"; Q2: “Does the market have to offer/develop tourist products with low environmental impact?"; Q3: "How worried do you feel when you think about climate change and the risks that 
it can cause?"; Q4: “To what extent are you willing to pay a supplementary fee on tour packages for environmental sustainability?"; Q5: "What percentage are you willing to pay for this extra fee?".

in the survey, the Likert scale was chosen to obtain opinions from tourists, since this is recommended in instruments that intend to measure opinions, beliefs or attitudes [41]. Seven levels of satisfaction were chosen, for the following reasons: (i) this method recognizes averages of perception; (ii) the respondent can be influenced by a shorter series of hypotheses and take refuge in the intermediate value [41]. In the Likert scale, ranging from 1 to 7 at the extremes, where 1 corresponds to "not very worried" and "Not at all willing" in Q3 and Q4, respectively, and 7 corresponds to: "very worried" and "very willing" in Q3 and Q4, respectively.

\subsection{Data Analysis}

The sample used in the study consisted of 1181 respondents, allowing us to know the characteristics of the participant, survey season, market and types of tourism, reported as frequency and percentage distribution.

Regarding the five questions of the questionnaire, the following statistical methods were used: frequency for Q1 and Q2; frequency, average, standard deviation and variation coefficient for Q3, Q4 and Q5; and correlation between Q3, Q4 and Q5. IBM SPSS Statistics was used for data analysis.

The search verifies the correlation between two nominal variables or one nominal variable and another ordinal. Pearson's correlation coefficient, also called "product-moment correlation coefficient", was used to measure the degree of correlation (and the direction of this correlation, i.e., positive or negative) between three variables ("To what extent do you feel concerned about climate change and the risks that can arise?" and the questions: "To what extent are you willing to pay a supplementary fee on tourism packages for environmental sustainability?" and "What percentage are you willing to pay for this additional fee?") of metric scale. This coefficient assumes values between -1 and 1 , indicating negative or positive correlation, respectively.

\section{Results}

The sample used in the study consisted of 1181 respondents. The sample integrates two markets, with 77\% originating from Northern Europe and 23\% from Southern Europe (Table 1).

Table 1. Characteristics of the participants (markets, tourism typology, gender, age, education qualification).

\begin{tabular}{ccc}
\hline & N & Percentage \\
\hline South Europe & 867 & $77 \%$ \\
North Europe & 265 & $23 \%$ \\
\hline "Sand and Sea" & 784 & $66 \%$ \\
Cultural & 397 & $34 \%$ \\
\hline Female & 620 & $55 \%$ \\
Male & 511 & $45 \%$ \\
\hline$<25$ years old & 238 & $20 \%$ \\
25-35 years old & 182 & $16 \%$ \\
36-45 years old & 93 & $8 \%$ \\
46-55 years old & 136 & $12 \%$ \\
56-65 years old & 242 & $21 \%$ \\
$>65$ years old & 273 & $23 \%$ \\
\hline Basic Education & 631 & $56 \%$ \\
High School & 431 & $38 \%$ \\
Higher Education & 71 & $6 \%$ \\
\hline
\end{tabular}

The surveys were answered by "sun and sea" tourists and cultural tourists, as they were the two most representative types of tourism in the Lisbon Metropolitan Area (66\% cultural tourism and 34\% "sun and sea" Tourism) (Table 1). 
The participants were $55 \%$ female and $45 \%$ male (Table 1 ), and $56 \%$ of the respondents had higher education, $38 \%$ had secondary or equivalent education and $6 \%$ had primary education (Table 2).

Table 2. Concern about climate change and the risks that it can cause and willingness to pay a supplementary fee on tour packages for environmental sustainability.

\begin{tabular}{ccccccc}
\hline & \multicolumn{5}{c}{ Standard } & Coef. of \\
\hline & $\mathbf{N}$ & Average & Deviation & Variation & Minimum & Maximum \\
\hline $\begin{array}{c}\text { Q3: “How worried do you feel when you think of } \\
\text { climate change and the risks it can cause?” }\end{array}$ & 1148 & 4.23 & 1.79 & $42 \%$ & 1 & 7 \\
\hline $\begin{array}{c}\text { Q4: “To what extent are you willing to pay } \\
\text { a supplementary fee on tour packages for } \\
\text { environmental sustainability" }\end{array}$ & 1143 & 3.31 & 1.73 & $52 \%$ & 1 & 7 \\
\hline
\end{tabular}

Regarding age classes, $20 \%$ were under 25 years old, $16 \%$ were between 25 and 35 years old, $8 \%$ were between 36 and 45 years old, 12\% were between 46 and 55 years old, 21\% were between 56 and 65 years old and $23 \%$ were over 65 years (Table 1 ).

An analysis of the answers to the following questions allowed the achievement of the specific objectives defined. We can conclude that $65 \%$ of tourists consider that products should have information about their ecological footprint (amount of $\mathrm{CO}_{2}$ emission) and almost $90 \%$ of the respondents consider that the market should offer/develop tourism products with low impact on the environment.

Therefore, we conclude that the market should develop tourism products with information about their ecological footprint and with low environmental impact, which will allow a more sustainable choice.

The responses were slightly above average variations (value 4). It shows the tourists were quite worried when they think of climate change and the risks that it can cause.

In the sample, on the measurement scale from " 1 " to " 7 ", the concern has an average value of 4.23 , with a dispersion of values of $42 \%$ (Table 2).

We can observe that tourists are concerned when tourists think about climate change and the risks that it can cause, since more than half of the sample answered between 4 and 7 on the Likert scale, with 7 being "very worried". With the standard deviation and coefficient of variation being relatively low, we can see that there was a growing concern among tourists about climate change issues.

When we asked tourists: "To what the extent are you willing to pay a supplementary fee on tour packages for environmental sustainability?", on a scale of 1 (not at all willing) to 7 (very willing), $19 \%$ said " 1 ", $16 \%$ said " 2 ", $21 \%$ said " 3 ", $20 \%$ said " 4 ", $12 \%$ said " 5 ", $6 \%$ said " 6 " and $6 \%$ said "7-very willing".

In the sample, on the scale of " 1 " to " 7 ", the provision to pay a supplementary fee presents an average value of 3.31 , with a dispersion of values of $52 \%$ (Table 3 ).

Table 3. Percentage that tourists are willing to pay for an extra fee.

\begin{tabular}{ccc}
\hline Q5: “What Percentage Are You Willing to Pay for This Extra Fee?” & N & Percentage \\
\hline $0 \%$ & 221 & $20 \%$ \\
$1-4 \%$ & 589 & $53 \%$ \\
$5-10 \%$ & 274 & $24 \%$ \\
$>10 \%$ & 274 & $24 \%$ \\
\hline
\end{tabular}

We conclude that while tourists were concerned about the risks associated with climate change, more than half of the sample was unwilling to pay the supplementary fee on tour packages for environmental sustainability.

In Q5 "What percentage are you willing to pay for this extra fee?", $20 \%$ of the respondents said that they are willing to pay $0 \%$ for the supplementary fee, $53 \%$ of respondents said that they are willing 
to pay $1-4 \%, 24 \%$ of respondents said that they are willing to pay $5-10 \%$ and $3 \%$ of respondents are willing to pay more than $10 \%$ for the extra fee (Table 3).

We conclude that more than half of the sample tourists who were willing to pay a supplementary fee for sustainability in tourist packages are willing to pay between $1-4 \%$. It should be noted that, on the one hand, $20 \%$ of tourists are not willing to pay a fee for environmental sustainability, while on the other hand, $24 \%$ of tourists are willing to pay it. This information is important to stakeholders (policy makers and tour operators).

In order to achieve the last objective-to relate tourists' perception of the impacts of climate change and the risks that may arise with the willingness to pay a fee and how much tourists are willing to pay-it is necessary to analyse the correlation between the question: "To what extent do you feel concerned about climate change and the risks that can arise?" and the questions: "To what extent are you willing to pay a supplementary fee on tourism packages for environmental sustainability?" and "What percentage are you willing to pay for this additional fee?".

There is a statistically significant relationship between: "To what extent do you feel worried when you think of climate change and the risks that can arise?" and: "To what extent are you willing to pay a supplementary fee on tour packages for environmental sustainability?" and "What percentage are you willing to pay for this extra fee?" (Table 4).

Table 4. Correlation: Q3 with Q4 and Q5 (Pearson's Correlation).

\begin{tabular}{cccc}
\hline & & $\begin{array}{c}\text { Q4: To What Extent Are You } \\
\text { Willing to Pay A Supplementary } \\
\text { Fee on Tourism Packages for } \\
\text { Environmental Sustainability? }\end{array}$ & $\begin{array}{c}\text { Q5: What Percentage Are You Willing } \\
\text { to Pay for This Additional Fee? }\end{array}$ \\
\hline $\begin{array}{c}\text { Q3: To what extent do you feel } \\
\text { worried when you think of climate } \\
\text { change and the risks that can arise? }\end{array}$ & $\begin{array}{c}\text { Correlation Coefficient } \\
\text { Probability value }\end{array}$ & 0.391 & 0.31 \\
& $\mathrm{~N}$ & $<0.001$ & $<0.001$ \\
& & 1123 & 1095 \\
\hline
\end{tabular}

These are positive relationships, revealing that those who are most concerned when thinking about climate change and the risks that may arise from it are more willing to pay a supplementary fee in the tourist packages for environmental sustainability and also more willing to pay a higher percentage for additional tax.

\section{Discussion}

According to several researchers, it is important to state that tourist information determines the tourists' perception, which in turn is influenced by different factors, e.g., climate, environment, income, discriminatory wealth, personal safety and household decision-making, among others.

In terms of perception and awareness of the impacts of climate change, most tourists believed that the market should offer/develop tourism products with low impact on the environment and believed that tourism products should provide information about their ecological footprint. The value of concern when tourists thought about climate change and the risks that may arise was slightly above the average value ( 4 on the Likert scale from 1 to 7 ).

When tourists are asked if they are concerned about the risks of climate change impacts, the affirmative answers were equal to or above the average. We can conclude that tourists are worried about the risks that can come from climate change.

The willingness to pay a supplementary fee in the tourist packages for environmental sustainability was below average (value 4 ). Being that $20 \%$ of the tourists were not willing to pay any amount, $56 \%$ of the tourists gave answers below the average value, and only $24 \%$ of the answers were above this value. This value agrees with the results obtained by Ardeshiri [42], which show that $14 \%$ of the tourists were not willing to pay any amount for the preservation of heritage.

The recorded figures show that tourists were still not very willing to pay a fee for environmental sustainability. 
These results were confirmed by Seetaram [43], who considered carbon taxation in air travel as an effective way of compensating for environmental externalities and adjusting tourist flows. However, despite the popularity of this rate, research shows that travellers' willingness to pay this tax in the UK remains low.

The results did not confirm the previous research [13,14,44-46] that showed that tourists were willing to purchase more expensive tourism packages with a fee for environmental sustainability. In the question of which value tourists were most willing to pay for a supplementary fee in tourism packages for environmental sustainability, most of affirmative answers were between $1 \%$ and $4 \%$. It should also be also noted that $20 \%$ of the valid answers indicated unwillingness to pay any amount for a supplementary fee.

The willingness to pay (WTP) a tax was influenced by different aspects: beach typology, whose value decreases from natural, semiurban and finally urban and sociometric indicators [43]; age and tourist nationality [46]; gender, education and income [44]; gender, age and length of stay [45]; and travel distance and air travel class [43].

It is concluded that since there was a positive correlation between the issues of "perception and awareness of environmental impacts" and the questions relating to "adaptation measures", those who were more aware of climate change environmental impact opt for more adaptive behaviours and were more willing to pay a fee in the tourism packages for environmental sustainability. It is also noted that those who were most concerned when thinking about climate change and the risks that may arise were more willing to pay a supplementary fee, and pay a higher value fee, on tour packages for environmental sustainability.

Lastly, for tourism and tourists, the climate represents both a vital resource to be exploited and an important risk to be managed. Consequently, it is expected that the demand for accurate and detailed information will substantially increase to lessen the challenges of the climate change in the coming decades.

\section{Conclusions}

This study allowed us to answer the main question of this paper: "Are tourists in the Lisbon region aware of the impacts of climate change, and how much of a fee are they willing to pay for environmental sustainability?"

To reach the objectives initially defined and to respond to research needs, contributing with information to the stakeholders, such as travel agencies, policy makers and insurers is needed to deal with the risks, increase resilience and facilitate the successful adaptation to the climate change.

The results obtained lead to the conclusion that it will be important for tourists to develop a sense of environmental responsibility, due to the impact that travel has on the environment. To achieve this objective, education for environmental sustainability will have to be carried out.

In addition to information and education initiatives, states could also assist companies in conducting energy audits, facilitating the implementation of Environmental Management Systems and providing incentives, for example, for the use of renewable energy sources. Climate change can be part of a broader risk management plan for tourism.

It was concluded that the adoption of a proactive and nonreactive approach to climate change would maximize the ability of tourism stakeholders to adapt successfully.

One of the most obvious limitations is the geographical scope of the research, which focused mainly on tourism in Western countries. Research on adapting to climate change in relation to tourism remains much less developed than that of other economic sectors, such as risk assessment among tourism operators on a consistent basis.

A holistic approach to tourism, with climate change and adaptation research, is needed to be able to conceptualize and identify the implications of climate change on the tourism sector. Understanding local responses to change is crucial in preparing not only businesses, but also communities and policy makers to respond together to change. 
Author Contributions: Conceptualization, F.C., A.L. and V.A.; Formal analysis, F.C. and A.L.; Funding acquisition, A.L.; Investigation, F.C. and A.L.; Methodology, F.C., A.L. and V.A.; Supervision, A.L. and V.A.; Writing-original draft, F.C.; Writing-review \& editing, A.L. All authors have read and agree to the published version of the manuscript.

Funding: This research was funded by FCT—Fundação para a Ciência e Tecnologia, I.P. (CEG project number: UID/GEO/00295/2019).

Conflicts of Interest: The authors declare no conflicts of interest.

\section{References}

1. Matzarakis, A.; de Freitas, C.; Scott, D. Advances in Tourism Climatology. Berichte des Meteorologischen Institutes der Universität Freiburg Nr. 12. 2004. Available online: https://www.researchgate.net/publication/ 233758996_Advances_in_Tourism_Climatology (accessed on 1 November 2016).

2. UNWTO, UNEP \& WMO. Climate Change and Tourism: Responding to Global Challenges. In Madrid, United Nations World Tourism Organization; United Nations Environment Program: Paris, France; World Meteorological Organization: Geneva, Switzerland, 2008.

3. Intergovernmental Panel on Climate Change-IPCC. Summary for policymakers. In Managing the Risks of Extreme Events and Disasters to Advance Climate Change Adaptation (1-19); A Special Report of Working Groups I and II of the Intergovernmental Panel on Climate, Change; Field, C.B., Barros, V., Stocker, T.F., Qin, D., Dokken, D.J., Ebi, K.L., Mastrandrea, M.D., Mach, K.J., Plattner, G.K., Allen, S.K., et al., Eds.; Cambridge University Press: Cambridge, UK; New York, NY, USA, 2012.

4. Intergovernmental Panel on Climate Change-IPCC. Climate Change: The Physical Science Basis; Contribution of Working Group I to the Fourth Assessment Report of the Intergovernmental Panel on Climate, Change; Solomon, S., Qin, D., Manning, M., Chen, Z., Marquis, M., Avery, K.B., Tignor, M., Miller, H.L., Eds.; Cambridge University Press: Cambridge, UK, 2007.

5. Santos, F.; Miranda, P. Alterações climáticas em Portugal. Cenários, impactos e medidas de adaptação. In Projeto SIAM II; Gradiva: Lisboa, Portugal, 2006.

6. Machete, R. Clima e turismo num contexto de mudanças climáticas. Finisterra 2011, 91, 139-154.

7. Gössling, S.; Scott, D.; Hall, C.M.; Ceron, J.P.; Dubois, G. Consumer behaviour and demand response of tourists to climate change. Ann. Tour. Res. 2012, 39, 36-58. [CrossRef]

8. European Commission. Special Eurobarometer 365: Attitudes of European Citizens Towards the Environment; European Commission: Brussels, Belgium, 2011.

9. World Travel and Tourism Council. WTTC Downgrades Global T\&T Growth Estimates for 2011 \& 2012; Maintains Long-Term Confidence. Press Release, 8 November 2011. Available online: https:/www.hospitalitynet.org/news/ 4053689.html (accessed on 1 November 2011).

10. Zaei, M.; Zaei, M. European centre for research training and development UK. Eur. J. Tour. Hosp. Res. 2013, 1, $12-21$.

11. Dowling, R.K.; Fennell, D.A. The context of ecotourism policy and planning. In Ecotourism Policy and Planning; Fennell, D.A., Dowling, R.K., Eds.; CABI: Wallingford, UK, 2003; pp. 1-20.

12. Chafe, Z. Consumer Demand and Operator Support for Socially and Environmentally Responsible Tourism; Centre on Ecotourism and Sustainable Development (CESD); The International Ecotourism Society (TIES): Washington, DC, USA, 2005.

13. Choi, G.; Parsa, H.G.; Sigala, M.; Putrevu, S. Consumers' environmental concerns and behaviours in the lodging industry: A comparison between Greece and the United States. J. Qual. Assur. Hosp. Tour. 2009, 10, 93-112. [CrossRef]

14. Dodds, R.; Graci, S.R.; Holmes, M. Does the tourist care? A comparison of tourists in Koh Phi Phi, Thailand and Gili Trawangan, Indonesia. J. Sustain. Tour. 2010, 18, 207-222.

15. Hedlund, T.; Nordvall, A.; Bengtsson, M. Swedish Tourists' Willingness to Pay for Environmentally Friendly Vacation Bundles; EMAC 2012 Conference; ISCTE: Lisboa, Portugal, 2012.

16. Viner, D. Tourism and its interactions with climate change. J. Sustain. Tour. 2006, 14, 317-322. [CrossRef]

17. UNWTO \& UNEP. Climate Change and Tourism: Responding to Global Challenges; Scott, D., Amelung, B., Becken, S., Ceron, J.P., Dubois, G., Gössling, S., Peeters, P., Simpson, M.C., Eds.; UNWTO: Madrid, Spain, 2008.

18. Becken, S.; Hay, J.E. Tourism and Climate Change: Risks and Opportunities; Channel View Publications: Clevedon, UK, 2007. 
19. Bigano, A.; Bosello, F.; Roson, R.; Tol, R.S.J. Economy-wide impacts of climate change: A joint analysis for sea level rise and tourism. Mitig. Adapt. Strateg. Glob. Chang. 2008, 13, 765-791. [CrossRef]

20. Gössling, S.; Hall, C.M. Uncertainties in predicting tourist travel flows based on models. Clim. Chang. 2006, 79, 163-173. [CrossRef]

21. Scott, D.; Lemieux, C. Weather and Climate Information for Tourism; Commissioned White Paper for the World Climate Conference 3; World Meteorological Organization: Geneva, Switzerland, 2009.

22. Nicholls, S. Climate change, tourism and outdoor recreation in Europe. Manag. Leis. 2006, 11, 151-163. [CrossRef]

23. Scott, D.; Lemieux, C. Weather and Climate Information for Tourism. Procedia Environ. Sci. 2010, 1, 146-183. [CrossRef]

24. Kang, S.K.; Hsu, C.H.C. Dyadic consensus on family vacation destination selection. Tour. Manag. 2005, 26, 571-582. [CrossRef]

25. Evangelista, F.; Dioko, L.A.N. Interpersonal influence and destination brand equity perceptions. Int. J. Cult. Tourism Hosp. Res. 2011, 5, 316-328. [CrossRef]

26. Hung, L.-S. Married couples' decision-making about household natural hazard preparedness: A case study of hurricane hazards in Sarasota County, Florida. Nat. Hazards 2017, 87, 1057-1081. [CrossRef]

27. Buzinde, C.N.; Manuel-Navarrete, D.; Yoo, E.E.; Morais, D. Tourists' perceptions in a climate of change. Ann. Tour. Res. 2010, 37, 333-354. [CrossRef]

28. Hall, C.M. Tourism: Rethinking the Social Science of Mobility; Pearson: Harlow, UK, 2005.

29. Scott, D.; Hall, C.M.; Gössling, S. Tourism and Climate Change: Impacts, Adaptation \& Mitigation; Routledge: London, UK, 2012.

30. Lopes, A.; Couto, J. Turismo, percepção e informação climática. Avaliação da informação disponibilizada aos viajantes. In "International Congress on Tourism", CIT 2010; Heritage \& Innovation: Porto, Portugal, 2010; pp. 357-364.

31. Scott, D. Climate change and sustainable tourism in the 21st century. In Tourism Research: Policy, Planning, and Prospects; Cukier, J., Ed.; Department of Geography Publication Series; University of Waterloo: Waterloo, ON, Canada, 2006.

32. Smith, K. The influence of weather and climate on recreation and tourism. Weather 1993, 48, 398-404. [CrossRef]

33. Scott, D.; Becken, S. Adapting to climate change and climate policy: Progress, problems and potentials. J. Sustain. Tour. 2010, 18, 283-295. [CrossRef]

34. Schuhmann, P.; Skeete, R.; Waite, R.; Lorde, T.; Bangwayo-Skeete, O.; Oxenford, H.; Gill, D.; Moore, W.; Spencer, F. Visitors' willingness to pay marine conservation fees in Barbados. Tour. Manag. 2019, 71, 315-326. [CrossRef]

35. Ndebele, T.; Forgie, V. Estimating the economic benefits of a wetland restoration programme in New Zealand: A contingent valuation approach. Econ. Anal. Policy 2017, 55, 75-89. [CrossRef]

36. Faizan, M.; Sasekumar, A.; Chenayah, S. Estimation of local tourists willingness to pay. Reg. Stud. Mar. Sci. 2016, 7, 142-149. [CrossRef]

37. Brouwer, R.; Brouwer, S.; Eleveld, M.; Verbraak, M.; Wagtendonk, A.; van der Woerd, H. Public willingness to pay for alternative managemenet regimes of remote marine protected areas in the North Sea. Mar. Policy 2016, 68, 195-204. [CrossRef]

38. Yu, B.; Cai, Y.; Jin, L.; Du, B. Effects on Willingness to Pay for Marine Conservation: Evidence from Zhejiang Province, China. Sustainability 2018, 10, 2298. [CrossRef]

39. Machete, R.; Andrade, H.; Couto, J. O turismo em Lisboa num Contexto de Alterações Climáticas-Cruzando Perspectivas. In Proceedings of the WSCRA2010-II Workshop Internacional sobre Clima e Recursos Naturais nos Países de Língua Portuguesa, Bragança, Portugal, 15-19 November 2010.

40. ATL-Associação de Turismo de Lisboa. Plano Estratégico 2011-2014. Available online: http://www.acif-ccim.pt/wpcontent/uploads/2018/Estudos/estudo_turismo_planoestrategico2011-2014.pdf (accessed on 9 November 2019).

41. DeVellis, R.F. Scale Development: Theory and Applications; Sage Publications, Inc.: Newbury Park, CA, USA, 1991.

42. Ardeshiri, A.; Ghasrodashti, R.; Rashidi, T.; Ardeshiri, M.; Willis, K. Conservation or Deterioration in Heritage Sites? Estimating Willingness to Pay for Preservation. 2019. Available online: http://arxiv.org/abs/1902.02418 (accessed on 12 July 2019).

43. Seetaram, N.; Song, H.; Ye, S.; Page, S. Estimating willingness to pay air passenger duty. Ann. Tour. Res. 2018, 72, 85-97. [CrossRef]

44. Kamri, T. Willingness to pay for conservation of natural resources in the Gunung Gading National Park, Sarawak. Procedia Social Behav. Sci. 2013, 101, 506-515. [CrossRef] 
45. Platania, M.; Rizzo, M. Willingness to pay for protected areas: A case of Etna Park. Ecol. Indic. 2018, 93, 201-206. [CrossRef]

46. Rodella, L.; Madau, F.; Mazzanti, M.; Corbau, C.; Carboni, D.; Utizi, K.; Simeoni, U. Willingness to pay for management and preservation of natural, semi-urban and urban beaches in Italy. Ocean Coast. Manag. 2019, 172, 93-104. [CrossRef] 